\title{
Serum Viscosity
}

National Cancer Institute

\section{Source}

National Cancer Institute. Serum Viscosity. NCI Thesaurus. Code C135572.

A measurement of the resistance of a serum sample to flow because of shear stress. 